DOI: $10.19195 / 2084-5065.52 .8$

\title{
The problematic scope of extended confiscation in comparative perspective
}

\author{
ARIADNA H. OCHNIO \\ ORCID: 0000-0003-1957-6942 \\ The Institute of Law Studies \\ Polish Academy of Sciences, Poland
}

\section{Introductory remarks}

Initially, the concept of extended confiscation in EU law was related to combating the most serious crime, however not every kind, but limited to having the nature of organised or terrorist crime. ${ }^{1}$ Under Framework Decision 2005/2012/JHA, extended powers of confiscation were still linked to this type of crime, as expressed in its Article $3 .^{2}$ Such a legal solution gave the extended powers of confiscation an attribute of extraordinariness, desirable because of their specificity. The concept then evolved towards breaking the link with the most serious crime, which is reflected in Directive 2014/42/EU. ${ }^{3}$ According to Article 5(2) of the Directive, the

1 This study was completed largely thanks to the research stay at the Max Planck Institute for Foreign and International Criminal Law, Freiburg im Breisgau (Germany), as part of research project no. 2018/02/X/HS5/01663, The Principles for Confiscating the Proceeds of Crime in French, German, and English Criminal Law, financed by the National Science Centre, Poland.

${ }^{2}$ Council Framework Decision 2005/212/JHA of 24 February 2005 on Confiscation of Crime-Related Proceeds, Instrumentalities and Property, OJ L 68, 15.3.2005, p. 49.

${ }^{3}$ Directive 2014/42/EU of the European Parliament and of the Council of 3 April 2014 on the freezing and confiscation of instrumentalities and proceeds of crime in the European Union, OJ L 127, 29.04.2014, p. 39. 
notion of "criminal offence," for the purpose of extended confiscation, shall include at least the following harmonised offences: corruption in the private and public sector, offences relating to participation in a criminal organisation, offences relating to pornography involving a child, offences relating to illegal system or data interference, offences punishable by a custodial sentence of a maximum of at least four years (according to the relevant instrument in Article 3 of Directive 2014/42/EU, or the relevant national law ${ }^{4}$ ).

Changing the approach to extended confiscation at the EU level could not be indifferent to the scope of its application in the domestic laws of Member States, in which this special instrument was harnessed to combat various types of crime, but not necessarily the most serious. The direction of changes has been set by the EU minimum rules themselves, which

4 Article 3 of Directive 2014/42/EU mentions the offences covered by the following Acts: "(a) Convention drawn up on the basis of Article K.3(2)(c) of the Treaty on European Union on the fight against corruption involving officials of the European Communities or officials of the Member States of the European Union ('Convention on the fight against corruption involving officials'); (b) Council Framework Decision 2000/383/ JHA of 29 May 2000 on increasing protection by criminal penalties and other sanctions against counterfeiting in connection with the introduction of the euro; (c) Council Framework Decision 2001/413/JHA of 28 May 2001 on combating fraud and counterfeiting on non-cash means of payment; (d) Council Framework Decision 2001/500/JHA of 26 June 2001 on money laundering, the identification, tracing, freezing, seizing and confiscation of instrumentalities and the proceeds of crime; (e) Council Framework Decision 2002/475/JHA of 13 June 2002 on combating terrorism; (f) Council Framework Decision 2003/568/JHA of 22 July 2003 on combating corruption in the private sector; (g) Council Framework Decision 2004/757/JHA of 25 October 2004 laying down minimum provisions on the constituent elements of criminal acts and penalties in the field of illicit drug trafficking; (h) Council Framework Decision 2008/841/JHA of 24 October 2008 on the fight against organised crime; (i) Directive 2011/36/EU of the European Parliament and of the Council of 5 April 2011 on preventing and combating trafficking in human beings and protecting its victims, and replacing Council Framework Decision 2002/629/JHA; (j) Directive 2011/93/EU of the European Parliament and of the Council of 13 December 2011 on combating the sexual abuse and sexual exploitation of children and child pornography, and replacing Council Framework Decision 2004/68/JHA; (k) Directive 2013/40/ EU of the European Parliament and of the Council of 12 August 2013 on attacks against information systems and replacing Council Framework Decision 2005/222/JHA". The cited Article 3 in fine also refers to other legal instruments clearly stating that Directive 2014/42/EU applies to the offences harmonised therein. 
it seems do not contain sufficient restrictions on offences triggering extended confiscation. This study focuses on the criteria for selecting the triggering offences as one of the pre-factors determining the scope of extended confiscation. Due to assumed thematic limitations, this study does not deal with other elements affecting the scope of extended confiscation.

The purpose of this study is to point out the current broad scope of triggering offences relevant to extended confiscation by comparing the choices made in the criminal law of selected Member States: Poland, Romania, Germany, Austria, France, Spain, Finland, and the Netherlands. Although the United Kingdom is not involved in the implementation of Directive 2014/42/EU, to broaden the research perspective, English legal solutions in this respect were taken into consideration, limited to the law applicable in England and Wales. The comparison allowed similarities and differences to be identified in the criteria adopted for the triggering offences. The analysis in this aspect seems all the more necessary as according to Article 13 of Directive 2014/42/EU, the Commission shall, by 4 October 2019, submit a report to the European Parliament and the Council, assessing inter alia the need to revise the list of offences in Article 5(2) of Directive 2014/42/EU. ${ }^{5}$

To better understand the importance of the growing scope of the application of extended confiscation in EU law, at the beginning it is worth asking the question as to what exactly is the speciality of extended confiscation. Its specificity results from the lack of a requirement for complete proof as to the origin of the property from crime among the prerequisites to order extended confiscation. Under current EU law, it is sufficient that: "a court, on the basis of the circumstances of the case, including the specific facts and available evidence, such as that the value of the property is disproportionate to the lawful income of the convicted person, is satisfied that the property in question is derived from criminal conduct" (Article 5 (1) of Directive 2014/42/EU). Recital 21 of the Preamble to Directive 2014/42/EU clarifies: "This does not mean that it must be established that the property in question is derived from criminal conduct. Member States may provide that it could, for example, be sufficient for the court to

5 Corrigendum to Directive 2014/42/EU of the European Parliament and of the Council of 3 April 2014 on the freezing and confiscation of instrumentalities and proceeds of crime in the European Union, OJ L 138, 13.05.2014, p. 114. 
consider on the balance of probabilities, or to reasonably presume that it is substantially more probable, that the property in question has been obtained from criminal conduct than from other activities. In this context, the court has to consider the specific circumstances of the case, including the facts and available evidence based on which a decision on extended confiscation could be issued. The fact that the property of the person is disproportionate to his lawful income could be among those facts giving rise to a conclusion of the court that the property derives from criminal conduct. Member States could also determine a requirement for a certain period of time during which the property could be deemed to have originated from criminal conduct."

The adjudication on the final deprivation of the property on the basis of an assumption, which is a substitute for "complete proof," means as a consequence burdening the judicial decision on extended confiscation with the large risk of error. Additionally, simplification in proving the origin of property raises doubts about the possibility of accepting such risk, especially for crime other than the most serious, bearing in mind the fundamental principles of criminal law and procedure. This side of the problem was pointed out by Johan Boucht, who aptly defined the specifics of "extended appropriation proceedings" by the inherent risk connected with incorrect decisions on confiscation, which may be addressed to licit property that entails further questions about the acceptable degree of increased risk and the appropriate methods to compensate for it. ${ }^{6}$

\section{Triggering offences in criminal law of selected Member States}

The next part of this study presents the current normative framework concerning triggering offences in selected European legal orders. The analysis of various extended confiscation regimes allowed for the indication of the similarities and differences in criteria for selecting such offences. To this end, criminal regulations regarding extended confiscation adopted in Poland (PL), Romania (RO), Germany (DE), Austria (AT), France (FR),

6 J. Boucht, The Limits of Asset Confiscation. On the Legitimacy of Extended Appropriation of Criminal Proceeds, Oxford-Portland 2017, pp. 233-234. 
Spain (ES), Finland (FI), the Netherlands (NL) and England and Wales (EN) have been compared. Legal systems from various legal traditions selected for the study have in common that they belong to the EU, with the proviso that the United Kingdom is not involved in the implementation of Directive 2014/42/EU. Nevertheless, analysis of regulations applicable to England and Wales broadens the research perspective because they are part of a system from the common law tradition.

\subsection{Normative framework}

Poland. Under the Polish Criminal Code, two independent criteria determine triggering offences. Firstly, the offence shall be one that caused material benefit of significant value. There is no legal definition for the term "material benefit of significant value," however, in this respect it is a possible auxiliary reference to the definition of "property of significant value," which is property whose value at the time the offence is committed exceeds 200,000 PLN (Article 115 (5) of the Criminal Code of 6 June 1997, Journal of Laws 1997, no. 88, item 553 with further amendments). Secondly, the offence shall be one that caused or could cause a material benefit (without any value requirements) and that is punishable by imprisonment for a maximum of not less than 5 years, or has been committed in an organised group or association aimed at committing an offence (Article 45(2) of the Criminal Code).

Romania. The Romanian Criminal Code provides for cumulative criteria regarding triggering offences listed in Article $112^{1}(1)$ (the Criminal Code of 17 July 2009, Law no. 286/2009, Official Gazette of Romania, 24 July 2009, no. 510 with further amendments). ${ }^{7}$ The requirements for such offences are as follows: the offence shall be one of the statutory cata-

7 For more on Romanian regulations concerning extended confiscation before the changes transposing the Council Framework Decision 2005/212/JHA (Law no. 63/2012 amending and supplementing the Criminal Code of Romania, Official Gazette of Romania, Part I, no. 258, 19.04.2012 and Law no. 286/2009 — the Criminal Code, Official Gazette of Romania, Part I, no. 510, 24.07.2009), see: T. Toader, M. Safta, "The Constitutionality of Safeguards on Extended Confiscation," Journal of Eastern-European Criminal Law 2015, no. 1, pp. 4-5; N.E. Buzatu, A. Uzlău, "Novelties in security measures — the extended seizure," AGORA International Journal of Juridical Sciences 2013, no. 3, pp. 19-25. 
logue, which is likely to cause a material benefit and is punishable by imprisonment of at least 4 years. The catalogue specified in the provisions of the Criminal Code covers the following types of offences: offences relating to drug trafficking and precursors, offences relating to trafficking in and exploitation of vulnerable persons, offences on the state border of Romania, the offence of money laundering, offences relating to the laws preventing and combating pornography, offences relating to the laws combating terrorism, establishment of an organised crime group, offences against property, non-observance of the law on weapons, ammunition, nuclear materials, explosive materials and restricted explosive precursors, counterfeiting of currency, stamps or other values, disclosure of economic secrecy, unfair competition, non-observance of the provisions on import and export operations, embezzlement of funds, offences relating to the import and export regime and the import and export of waste and residues, gambling offences, corruption offences and offences related thereto, offences against the financial interests of the EU, tax evasion offences, offences relating to the customs regime, offences committed via computer systems and electronic means of payment, trafficking in organs, tissues or cells of human origin.

Germany. According to the German Criminal Code an offence triggering extended confiscation may be any criminal offence (without restrictions). The deprivation concerns the objects of the perpetrator or participant even obtained through other than considered unlawful acts or for them. After the legislative changes of 13 April 2017, that entered into force on 1 July $2017,{ }^{8}$ extended confiscation is no longer associated with the listed offences (Section 73a of the Criminal Code of 15 May 1871, in the version published on 13 November 1998, BGB 1 I p. 3322, with further amendments). The above mentioned law of 13 April 2017 was entitled "Law on the reform of criminal asset recovery." The significance of the changes to the extended confiscation resulting from this reform lies in breaking its link with serious crime, in particular of an organised or professional

8 Law on the reform of criminal asset recovery [Gesetz zur Reform der strafrechtlichen Vermögensabschöpfung], 13 April 2017, Federal Law Gazette, Part I 2017, no. 22, 21.04.2017. 
nature, which was previously provided for in German criminal law (old version of Section $73 \mathrm{~d}$ of the Criminal Code). ${ }^{9}$

Austria. The concept of extended confiscation in Austrian criminal law (national legal term: "extended forfeiture") links it to serious crime by the conditions set for the assets that can be forfeited (Section 20b(1) of the Austrian Criminal Code, Federal Act of 23 January 1974 on actions threatened with legal punishment - Criminal Code AT, StGB, StF: BGB 1 No. 60/1974, with further amendments). The application of extended confiscation is limited to the assets at the disposal of a criminal organisation (Section 278a of the Criminal Code) or a terrorist organisation (Section $278 \mathrm{~b}$ of the Criminal Code) or the assets provided or collected as means of financing terrorism (Section $278 \mathrm{~d}$ of the Criminal Code). Additionally, if the unlawful act has been committed pursuant to Sections 165, 278, 278c of the Criminal Code ${ }^{10}$ for the commission of which or through which the assets have been obtained or in the commission of such a crime, also those assets shall be forfeited that were obtained in a temporal relation to this act, if it is reasonable to assume that they come from an unlawful act and their legitimate origin cannot be justified. This should also be noted regarding the extended scope of forfeiture in relation to offences committed abroad. Under Section 65a of the Criminal Code, extended forfeiture also applies to domestic assets in relation to acts that are punishable by

${ }^{9}$ For more on the previously stricter conditions for ordering confiscation set out in the German Criminal Code, see: A.H. Ochnio, "Konfiskata rozszerzona w prawie wybranych państw europejskich," Prokuratura i Prawo 2016, no. 12, pp. 111-114; J. Benseler, "Forfeiture Legislation in Germany: Legal Basis and Prosecution Practice," European Journal of Crime, Criminal Law and Criminal Justice 5, 1997, no. 3, pp. 203209. Compare: U. Sieber, "The New Architecture of Security Law — Crime Control in the Global Risk Society," [in:] Alternative Systems of Crime Control National, Transnational and International Dimensions, eds. U. Sieber et al., "Research Series of the Max Planck Institute for Foreign and International Criminal Law, Reports on Research in Criminal Law," vol. S 161, Berlin-Freiburg i. Br. 2018, pp. 10-11.

10 These are the following offences: money laundering (Section 165 of the Criminal Code of Austria), criminal association (Section 278 of the Criminal Code of Austria), terrorist offences (Section 278c of the Criminal Code of Austria). See also: M. LöschnigGspandl, "Fight against Organized Crime: Recent Changes to the Catalogue of Statutory Offences and the Confiscation System in Austrian Criminal Law," European Journal of Crime, Criminal Law and Criminal Justice 5, 1997, no. 3, pp. 217-218. 
the laws of the crime scene while not subject to the criminal jurisdiction of Austria.

France. The application of extended confiscation under French criminal law is limited to crimes and offences punishable by imprisonment for at least 5 years. According to Article 111 (1) of the Criminal Code, criminal offences are categorised in the French criminal law system by the criterion of their severity as crimes, offences and contraventions (in other words: felonies, misdemeanours, petty offences). An additional requirement is that they shall procure direct or indirect benefit ${ }^{11}$ (Article 131-21 al. 5 of the Criminal Code, promulgated on 22 July 1992, consolidated version of 3 August 2019). ${ }^{12}$

Spain. According to the Spanish Criminal Code, triggering offences are those listed in Article 127bis (1), (Ley Orgánica 10/1995, the Criminal Code of 23 November 1995, Official State Bulletin of 24 November 1995, no. 281, with further amendments ${ }^{13}$ ). The requirements include conviction for one of the listed offences and the judicial recognition that the assets come from criminal activity and its legal origin has not been proven. The listed offences relevant to extended confiscation are as follows: human trafficking, organ trafficking, offences relating to prostitution and corruption of minors, sexual abuse and aggression against children under sixteen, selected computer offences, offences against property and against the socioeconomic order in cases of criminal continuity and recidivism, offences relating to punishable insolvencies, offences against intellectual or industrial property, corruption in the private and public sector, receiving (Article 298 (2) of the Criminal Code), money laundering, offences against the Treasury and Social Security, offences against the rights of labour (Articles 311-313 of the Criminal Code), offences against the rights of foreigners, offences against public health (Articles 368-373 of the Crim-

11 On the conditions relating to confiscation in French criminal law, see: N. Lory, La saisie pénale des biens incorporels, Paris 2016, pp. 37-39; F. Desportes, F. Le Gunehec, Droit pénal général, Paris 2009, p. 797. For more on the history of the confiscation regime in France, see: A. Kletzlen, T. Godefroy, "Confiscation and Anti-Money-Laundering Regulations under French law," European Journal of Crime, Criminal Law and Criminal Justice 5, 1997, pp. 273-280.

12 https://www.legifrance.gouv.fr/affichCode.do?cidTexte=LEGITEXT00000607 0719\&dateTexte=20190905 (accessed: 5.09.2019).

13 https://www.boe.es/eli/es/lo/1995/11/23/10/con (accessed: 6.09.2019). 
inal Code), counterfeiting of currency, embezzlement, terrorist offences, offences committed within an organisation or crime group. ${ }^{14}$

Finland. The first requirement for triggering offences under Finnish criminal law is its ability to bring financial benefits. The second requirement is the offence belonging to a statutory catalogue that includes offences punishable by a penalty of specified severity and other specifically enumerated offences (Chapter 10, Section 3 of the Criminal Code, 19 December 1889, Law Gazette no. 39, 1889, with further amendments ${ }^{15}$ ). Firstly mentioned are offences punishable by a maximum term of imprisonment of at least 4 years. Secondly mentioned are listed offences: hiding crime or money laundering (the extension to persons and other entities is possible under certain conditions relating to the relationship), smuggling, offences relating to drugs, active and passive corruption in the private and public sector, participation in the activities of an organised crime group, offences relating to disseminating sexually suggestive images and attracting a child for sexual purposes, causing a threat to data processing. A punishable attempt is sufficient regarding all these offences. ${ }^{16}$

The Netherlands. Under the Dutch Criminal Code, extended confiscation takes the form of a court decision obliging to pay a sum of money to the State. ${ }^{17}$ Such an obligation to pay a sum of money for the deprivation of unlawfully obtained benefit may be imposed for the commission of an offence threatened with a fine of the fifth category, when it is likely that this offence or other offences are potentially lucrative, i.e. in any way have led to the unlawful benefit of the sentenced person (Article 36e (2), (3) of

14 For more on the previous regulation concerning confiscation in Spanish criminal law, see: P. Faraldo Cabana, "General confiscation regulation in Spain," Journal of Money Laundering Control 13, 2010, no. 2, pp. 109-124.

15 https://www.finlex.fi/fi/laki/ajantasa/1889/18890039001\#L10 (accessed: 11.09.2019).

16 The contemporary concept of extended confiscation in Finnish criminal law was examined by Malin Thunberg Schunke, see: M.T. Schunke, Extended Confiscation in Criminal Law. National, European and International Perspectives, Cambridge-AntwerpPortland 2017, pp. 185-187.

17 For more on the historical regulations concerning confiscation in Dutch criminal law, see: C. Daams, I. van de Reyt, “'Strip-Them' Legislation in the Netherlands: Measures Concerning Confiscation of Illegally Obtained Profit in the Dutch Law," European Journal of Crime, Criminal Law and Criminal Justice 5, 1997, no. 3, pp. 308-313. 
the Criminal Code of 3 March 1881, version for 1 August 2019, no. BWBR0001854 ${ }^{18}$ ). The Dutch Criminal Code provides for six categories of fine defined by its following maximum amount (some differentiation is possible): the first category - 415 Euro, the second category - 4,150 Euro, the third category - 8,300 Euro, the fourth category - 20,750 Euro, the fifth category - 83,000 Euro, the sixth category - 830,000 Euro (Article 23(4) of the Criminal Code). The fine of the fifth category, which is the penultimate on the severity scale, may be imposed for many offences of rather serious gravity.

England and Wales. The extended confiscation regime applicable to England and Wales provides, in a manner somewhat similar to Dutch criminal law, a court decision on the recoverable amount and confiscation order requiring that amount be paid. ${ }^{19}$ One of the stages of making a confiscation order by the court is to determine, based on a balance of probabilities, whether the defendant has a criminal lifestyle, if so, whether he has benefited from his general criminal conduct, and if not, whether he has benefited from his particular criminal conduct (Section 6 (4), (5), (7) of the Proceeds of Crime Act 2002, UK Public General Acts, 2002 c. 29 , revised ${ }^{20}$ ). However, this stage of procedure is preceded by the fulfilment of two conditions. The first condition is that a defendant is convicted of an offence or offences in proceedings before the Crown Court (the Crown Court deals with more serious offences) or he is committed to the Crown Court for sentence in respect of a selected offence or offences under the Sentencing Act (Section 3, 3A, 3B, 3C, 4, 4A or 6 of the Powers of Criminal Courts (Sentencing) Act 2000, UK Public General Acts 2000 c. 6 , revised ${ }^{21}$ ), or he is committed to the Crown Court in respect of an

18 https://wetten.overheid.nl/BWBR0001854/2019-08-01 (accessed: 6.09.2019).

19 For more on the concept of criminal confiscation in law applicable in England and Wales, see: T. Millington, M.S. Williams, The Proceeds of Crime. Law and Practice of Restraint, Confiscation, Condemnation and Forfeiture, Oxford-New York 2018, pp. 1-14; K. Bullock, S. Lister, "Post-Conviction Confiscation of Assets in England and Wales: Rhetoric and Reality," [in:] Dirty Assets. Emerging Issues in the Regulation of Criminal and Terrorist Assets, eds. C. King, C. Walker, Farnham-Burlington 2014, pp. 53-55; D.J. Dickson, "Towards more effective asset recovery in Member States the UK example," ERA-Forum 10, 2009, no. 3, pp. 435-451.

$20 \mathrm{http}: / / w w w . l e g i s l a t i o n . g o v . u k / u k p g a / 2002 / 29 /$ contents (accessed: 9.09.2019).

21 http://www.legislation.gov.uk/ukpga/2000/6/contents (accessed 9.09.2019). 
offence or offences under section 70 of the Proceeds of Crime Act (committal with a view to a confiscation order). The second condition is that the prosecutor asks the court to proceed under this Section, or the court believes it is appropriate for it to do so (Section 6 (2), (3) of the Proceeds of Crime Act). According to the interpretation of a "criminal lifestyle" under Section 75 of the Proceeds of Crime Act, the offence (or any of the offences) concerned should be specified in Schedule 2 or should constitute conduct forming part of a course of criminal activity or should be an offence committed over a period of at least six months and the defendant should have benefited from the conduct which constitutes the offence. Schedule 2 lists lifestyle offences, which are (in general): drug trafficking, money laundering, directing terrorism, slavery, people trafficking, arms trafficking, counterfeiting, offences against intellectual property, prostitution and child sex, blackmail, offences relating to acting as a gangmaster, and inchoate offences. As far as offences outside Schedule 2 are concerned, an additional requirement is that the defendant should obtain relevant (defined by law) benefit of not less than $£ 5,000$.

\subsection{Criteria for triggering offences - similarities and differences}

The analysis of the criminal regulations of selected Member States concerning extended confiscation allowed the following recurrent similar criteria for triggering offences to be identified:

1. a reference to a material/financial benefit, or object, depending on the legal system: real or potential (the criminal law of PL, RO, DE, ES, FI, NL, EN, AT, FR),

2. a reference to a benefit of statutory specified value (the criminal law of PL, EN),

3. a reference to the threat of punishment with a statutory specified severity: imprisonment (the criminal law of PL, FR, FI) or fine (the criminal law of NL),

4. a list of offences (the criminal law of RO, AT, ES, FI, EN).

Some differences may be indicated between the criminal regulations examined. The first difference relates to whether the benefit should be real or potential, the latter appears in the criminal law of PL, RO, FI. The second significant difference, which also determines the severity of con- 
ditions enabling extended confiscation, is the difference related to whether the law requires all or some of the criteria indicated in points $1-4$, and which ones are cumulative and which are separable. The third difference is the criterion linking extended confiscation to crime of an organised or terrorist nature. A general reference to an offence of an organised nature can be found in Polish criminal law. In Austrian criminal law a general reference is made to the assets at the disposal of a criminal or terrorist organisation or the assets provided or collected as a means of financing terrorism. Nevertheless, organised and terrorist crime belongs to the scope of triggering offences, depending on the national legal system, by the use of various references direct or indirect, for example, through a general reference to the severity of punishment, or by an exact indication on the list of triggering offences. In addition, statutory catalogues cover many other offences that are usually committed within organised crime, like drug trafficking, human trafficking, money laundering, etc.

What draws special attention among the examined national regulations is the wide range of possibilities to order extended confiscation in German criminal law after the legislative changes of 13 April 2017, that entered into force on 1 July 2017. Current German criminal law is distinguished by the lack of requirements for triggering offences. It is significant that this reform of the German Criminal Code was introduced with the justification for compliance with Directive 2014/42/EU. ${ }^{22}$ Criminal regulations applicable in England and Wales are distinguished by an original and quite multi-faceted legal premise for extended confiscation, which is a 'criminal lifestyle'.

Finally, there are differences in sets of triggering offences resulting from the criteria of the threat of punishment or the amount of benefit and those covered by the statutory lists in the criminal law of Member States. These catalogues cover, for instance through a disjoint general reference to the threat of punishment or the amount of benefit, the offences which, depending on the criteria adopted, could be considered as belonging to even a medium crime.

22 See: Gesetzentwurf der Bundesregierung Entwurf eines Gesetzes zur Reform der strafrechtlichen Vermögensabschöpfung, Bundesrat, Drucksache 418/16, 12.08.16. 


\section{Conclusion}

The boundaries between medium and serious crime vary depending on the doctrinal approach. The matter is further complicated by differences in national criminal law systems in this respect, as this division is determined by a complex of factors, different within each system. Hence the difficulty in finding a common premise that could serve as "a red light" in EU law to limit the application of extended confiscation to combat serious, and not medium, crime. ${ }^{23}$ Recent changes in German criminal law show that even lighter than medium severity crime can be covered by extended confiscation and EU law does not provide adequate safeguards against the development of national law in such a direction. Lack of any requirement for triggering offences deprives this measure of its special character. On the margins of consideration, it should be noted that voices have already been raised in the German public space expressing doubts about the compatibility of the reform of the confiscation regime of 2017 with the Constitution. ${ }^{24}$

Referring to the upcoming evaluation by the Commission of the list of offences in Article 5(2) of Directive 2014/42/EU, it seems that the problem is not entirely in the list of triggering offences in this Directive, but also in the guidelines (soft) and conditions (strict) for applying extended confiscation in national legal orders. To ensure that the EU concept of extended confiscation as transferred to national legal systems passes the assessment of its proportionality, which will be successively carried out by national constitutional courts, the Court of Justice of the EU (CJEU) and the European Court of Human Rights (ECHR), the EU legislator should introduce some safeguards into EU law, at least at the level of soft guidelines in the preamble of Directive 2014/42/EU. These guidelines should clearly indicate that extended confiscation is an extraordinary measure of legal response to the most serious and serious crimes, the limits of which are set by a set of rules adopted in each of the Member States' criminal law system. Return to linking this measure with the most serious crimes

23 Malin Thunberg Schunke points out 'a shift' towards application of extended confiscation to all types of criminal offences, see: M.T. Schunke, op. cit., pp. 323-324.

24 For example, see: Stellungnahme no. 15/2016, Juni 2016, Zum Referentenentwurf zur Reform der strafrechtlichen Vermögensabschöpfung, Bundesrechtsanwaltskammer, https:/www.brak.desstellungnahme-der-brak-2016-15 (accessed: 13.09.2019). 
should be assessed as being difficult to achieve in relation to the objectives and arguments (although often inconsistent) presented in justification of the proposals of the EU legal acts concerning confiscation. ${ }^{25}$ Nevertheless, some improvement in the concept of extended confiscation at the EU law level seems achievable. It is worth postulating to deepen understanding of the speciality of extended confiscation on the part of Members States' legislators, especially in terms, as indicated in the cited literature, of its accompanying inseparable risk of judicial error, whose acceptance cannot relate to medium crime. In this respect, at least the improvement of the preamble of Directive 2014/42/EU towards emphasising the necessity of the extraordinary use of extended confiscation in national legal orders reserved for the most serious and serious crimes, the limits of which determine a multifaceted set of factors within each national legal order, would be helpful. This could also serve as a point of reference for the national constitutional courts, CJEU and ECHR when assessing inter alia the proportionality of the concrete regulations of extended confiscation adopted in a national legal system.

\section{References}

Benseler J., "Forfeiture Legislation in Germany: Legal Basis and Prosecution Practice," European Journal of Crime, Criminal Law and Criminal Justice 5, 1997, no. 3.

Boucht J., The Limits of Asset Confiscation. On the Legitimacy of Extended Appropriation of Criminal Proceeds, Oxford-Portland 2017.

Bullock K., Lister S., "Post-Conviction Confiscation of Assets in England and Wales: Rhetoric and Reality," [in:] Dirty Assets. Emerging Issues in the Regulation of Criminal and Terrorist Assets, eds. C. King, C. Walker, Farnham-Burlington 2014.

Buzatu N.E., Uzlău A., "Novelties in security measures - the extended seizure," $A G$ ORA International Journal of Juridical Sciences 2013, no. 3.

Daams C., van de Reyt I., “'Strip-Them' Legislation in the Netherlands: Measures Concerning Confiscation of Illegally Obtained Profit in the Dutch Law," European Journal of Crime, Criminal Law and Criminal Justice 5, 1997, no. 3.

Desportes F., Le Gunehec F., Droit pénal général, Paris 2009.

Dickson D.J., "Towards more effective asset recovery in Member States - the UK example," ERA Forum 10, 2009, no. 3.

25 See: A.H. Ochnio, "Between the medium and the minimum options to regulate mutual recognition of confiscation orders," New Journal of European Criminal Law 9 , 2018, no. 4, pp. 432-445. 
Faraldo Cabana P., "General confiscation regulation in Spain," Journal of Money Laundering Control 13, 2010, no. 2.

Kletzlen A., Godefroy T., "Confiscation and Anti-Money-Laundering Regulations under French law," European Journal of Crime, Criminal Law and Criminal Justice 5, 1997, no. 3.

Lory N., La saisie pénale des biens incorporels, Paris 2016.

Löschnig-Gspandl M., "Fight against Organized Crime: Recent Changes to the Catalogue of Statutory Offences and the Confiscation System in Austrian Criminal Law," European Journal of Crime, Criminal Law and Criminal Justice 5, 1997, no. 3.

Millington T., Williams M.S., The Proceeds of Crime. Law and Practice of Restraint, Confiscation, Condemnation and Forfeiture, Oxford-New York 2018.

Ochnio A.H., "Between the medium and the minimum options to regulate mutual recognition of confiscation orders," New Journal of European Criminal Law 9, 2018, no. 4.

Ochnio A.H., "Konfiskata rozszerzona w prawie wybranych państw europejskich," Prokuratura i Prawo 2016, no. 12.

Schunke M.T., Extended Confiscation in Criminal Law. National, European and International Perspectives, Cambridge-Antwerp-Portland 2017.

Sieber U., "The New Architecture of Security Law — Crime Control in the Global Risk Society," [in:] Alternative Systems of Crime Control National, Transnational and International Dimensions, eds. U. Sieber et al., "Research Series of the Max Planck Institute for Foreign and International Criminal Law, Reports on Research in Criminal Law," vol. S 161, Berlin-Freiburg i. Br. 2018.

Toader T., Safta M., "The Constitutionality of Safeguards on Extended Confiscation," Journal of Eastern-European Criminal Law 2015, no. 1.

\section{Summary}

The scope of extended confiscation is determined, inter alia, by the choice of triggering offences in Directive 2014/42/EU of the European Parliament and of the Council of 3 April 2014 on the freezing and confiscation of instrumentalities and proceeds of crime in the European Union. The question arises whether EU law guarantees appropriate limits of extended confiscation considering its specificity and the growing range of application in national legal orders. The study compared the normative framework of extended confiscation adopted in the criminal law of Poland, Romania, Germany, Austria, France, Spain, Finland, the Netherlands, and England and Wales. The list of offences, relevant for the scope of extended confiscation, is to be assessed by the Commission by 4 October 2019. The conclusions of the study concern the need to introduce, at the level of EU law, adequate safeguards against the disproportionate application of extended confiscation.

Keywords: extended confiscation, forfeiture, proceeds of crime, triggering offences, harmonised offences, proportionality 